Historic, Archive Document

Do not assume content reflects current scientific knowledge, policies, or practices. 


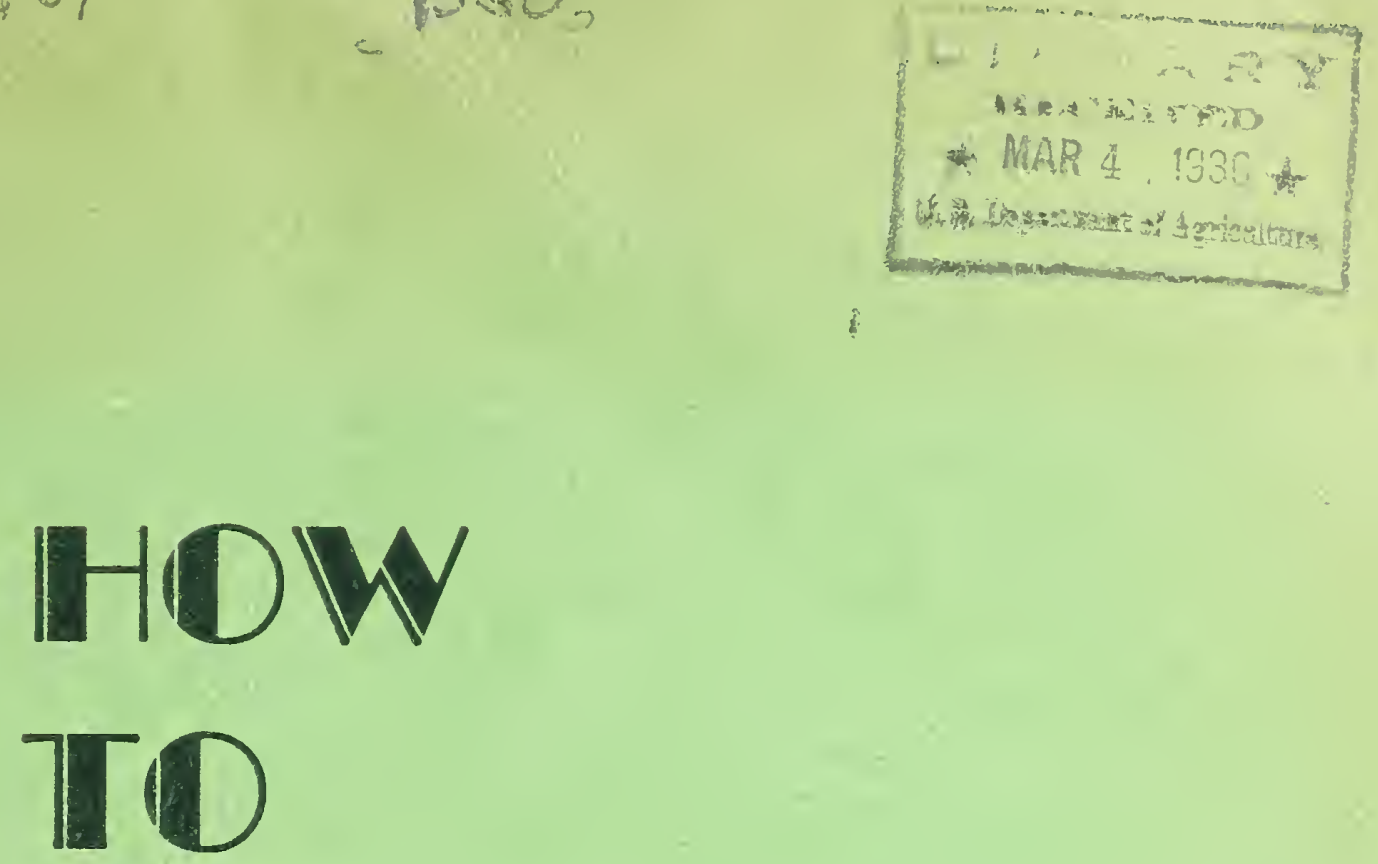

GIRWW
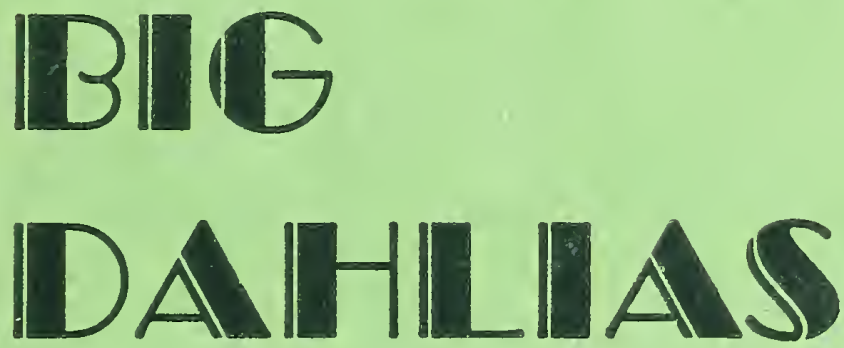



\section{How To Grow Big Dahlias}

Quite a few write for our catalog who have never before undertaken to produce for themselves those im. mense Dahlias they have admired in the gardens of others. To this group we offer some practical suggestions based on our own experience-and if the beginner finds any point not covered entirely to his satisfaction, we would like him to write us about it.

If you can grow a good vegetable garden, you can grow good Dahlias. There is nothing hard about it. First of all, it is important to be sure that the Dahlias you plant come from a reliable grower. You can then be certain that you will receive the varieties you ordered; that your stock has not been forced to the point of weakness by over-stimulation; and that the grower feels responsible if the roots do not come up.

Mention, when you order, what date you would like to have the roots delivered. Should you fail to do this, it is possible that your roots may arrive weeks before (or after) you are ready for them. The grower has much better storage facilities than his customer, and is able to keep them in fine shape until the date you specify.

In the meantime, you can have your garden made ready. It should be plowed or spaded up as deeply as possible, then harrowed or smoothed off with a rake. Then, when your roots come, you are ready to plant. If you have a large plot, and intend to have them cultivated with a horse, you should plant them about three feet apart in rows that are four feet apart. But you can safely set them a little closer together if your cultivation will be done by hand. The best time to plant in the latitude of New Jersey is in May or June. We try to have all planting and replanting done on our farms by the Fourth of July. Roots planted later may bloom, but frost cuts them down before many flowers have been borne.

If you are planting roots, lay the end with the eye (the crown end) exactly where you'd like your hill to come up. Place the root horizontally-not upright--deep enough so that you can cover it with two or three inches of soil.

If you are setting out green plants, treat them as you would spotted tomato plants. Don't wash the soil from the roots of plants purchased from us! Every bit of soil from our propagating house has been sterilized with carbon disulphide. It is not caked. Just remove the paper pot and plant the ball of soil. Then keep the baby bush shaded during the hottest part of the first few days. Water when you plant, and later if the ground is dry, and the plant will soon become established.

If you are planting both Dahlia roots and green plants, it is well to set out the green plants first-for it takes a little longer for plants to begin blooming than for roots. Try not to set green plants out after a period of very wet weather, especially if the plot was grass sod the previous year. The reason is cut worms, which thrive in both sod and wet weather. Plant your roots in the sod ground if you can make a choice. The cut worm does no serious damage, for a Dahlia, when cut off, will usually come up again from the root even when green plants are used. But they retard the plant growth.

There is much talk about roots versus green plants. We think their relative merits depend upon what is desired. If big blooms are the goal toward which you are striving, there is no doubt but what plants are every bit as good as roots. If you want good clumps of roots at

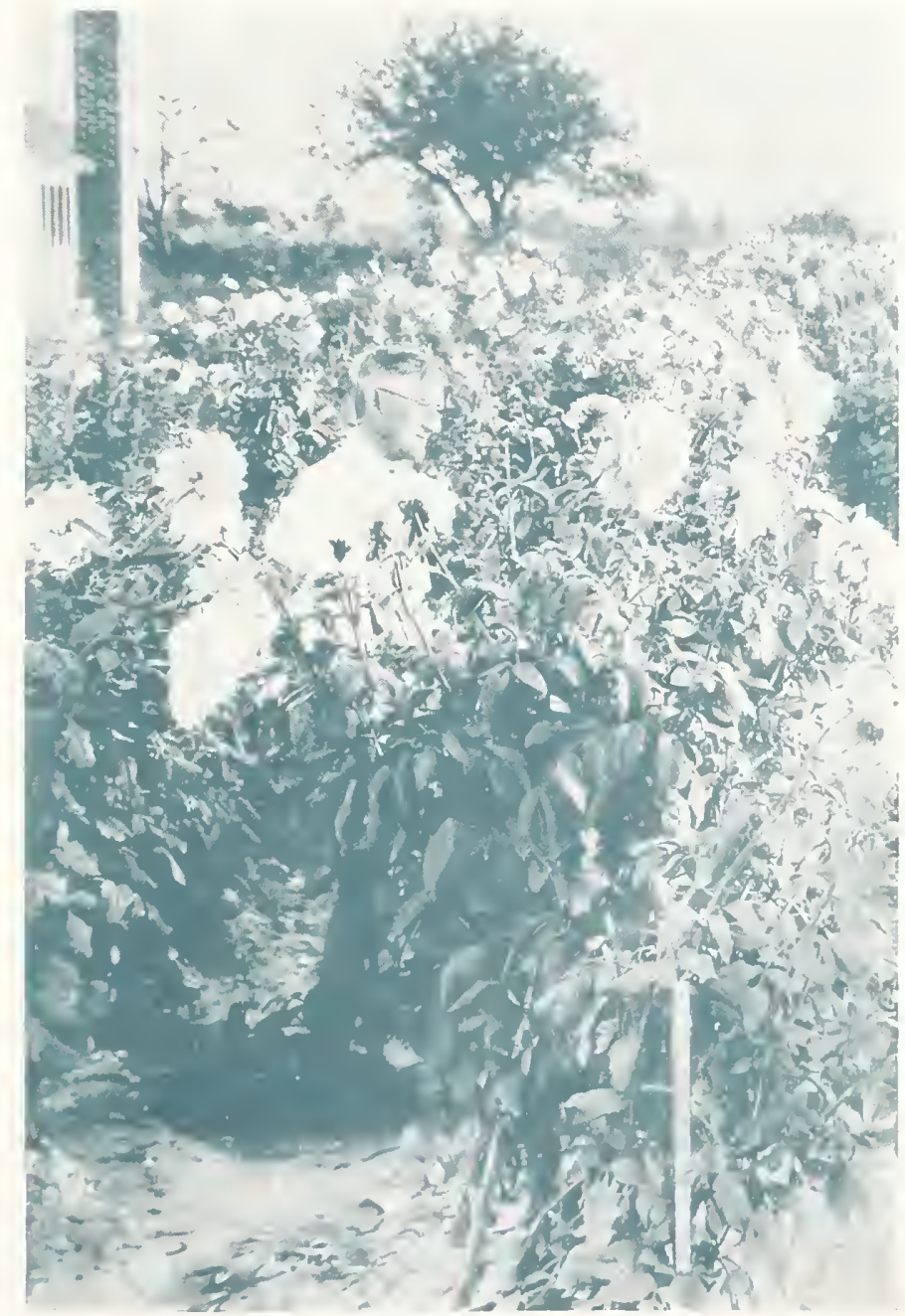




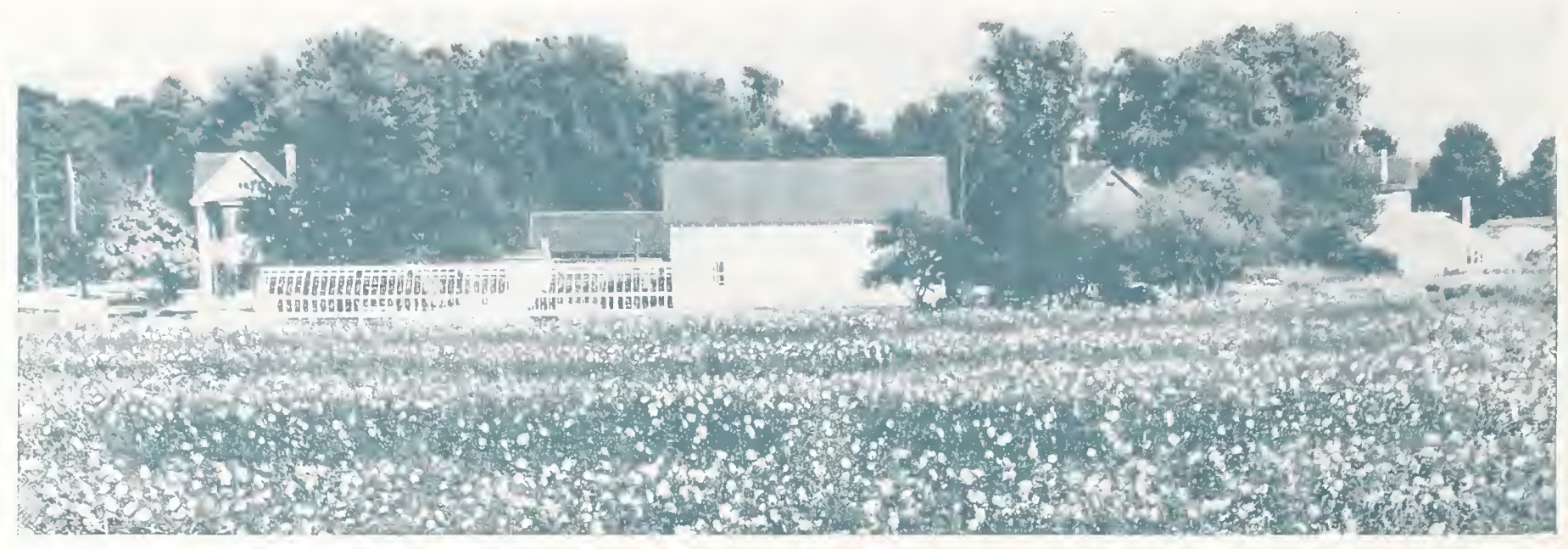

digging time in addition to the fine flowers, we think roots are the best provided they are planted at the same time as the plants. It has been our experience that plants will produce just as nice clumps as roots of the same variety if they are planted earlier-for it takes a green plant longer to mature. Taking these facts into consideration, and bear. ing in mind that you can buy two plants for the price of one root, it should not be hard for you to decide whether you want to put out roots or green plants. Bushes from roots bloom quicker and produce better clumps than green plants set out at the same time. Bushes from green plants, requiring a little more care in starting and costing only half as much, bear fully as fine flowers. Then, too, the bushes from green plants will produce clumps if given a little more time than roots of the same kind require. We have shipped green plants successfully from our farms in New Jersey as far as the State of Washington.

If your Dahlias are not planted in a spot where no wind can strike them, it is very important that they be staked up so that they are braced during storms-for the Dahlia bush is very heavy when loaded with blooms. The stakes should be about four feet long by one inch square, pointed on one end. We have tried many kinds of wood, but find that oak stands the pounding of being driven much better without splintering than other kinds. The most reasonable place to buy these stakes is at a country sawmill. Get your Dahlia growing friends to lump their orders with yours and the price will not be high.

Many growers drive their stakes when their roots are planted. We do not drive ours until our plants are about eighteen inches high--tall enough to take their first tying up. We are then not hampered by stakes during the earliest cultivation of the soil. After the stakes are solidly driven, the stalks of the bushes are tied-- not too tightlyto the stakes with binder twine, which is coarse enough not to cut the stalks. This tying up is re, peated whenever the bush grows far enough above the former tying to require it. No more than three tyings should be necessary to protect your patch in hard wind.

One of the most important steps in growing large blooms is disbudding. When the buds form there are usually three of them at the top of each stalk. The center one is called the terminal bud, and the two others lateral buds. Remove the two lateral buds and allow the center one to remain. Down the stalk, shoots will appear at each leaf joint. These, if allowed to grow, will form branches having more buds. Remove them from several joints below the terminal bud and you will thus concentrate the nutriment that nature intended for several buds into the one remaining on top of the stalk, forcing it to grow much larger than its natural size. This practice is called disbudding. It should also be practiced on the lateral branches. Where the very largest Dahlias are desired, disbudding is often followed so rigidly that only a very few blooms are allowed to develop on the entire bush-sometimes only one. See the drawing at the bottom of this page.

Often certain varieties will produce bushes so dense with foliage that it is impossible for sunlight to reach all parts of the plant. When this occurs it is a good idea to cut out some of the branches where their absence will do the most good. This not only permits more light but throws more nutriment into the bush remaining.

Don't water your Dahlias unless exceptionally dry weather makes it absolutely necessary-then soak them thoroughly. It is a good practice to cultivate after every rain, if possible, to prevent the moisture from evaporating from the soil.

Great care should be used in cultivating after the bushes are pretty well grown, for then the feed roots are usually so near the top of the soil that cultivating damages them. Feed roots will often stretch out from adjoining rows until they meet between. We never cultivate after the bushes begin to bloom.

Sometimes at this stage of growth straw is spread over the ground in small gardens to make a mulch that conserves moisture and keeps down weeds. Mulch paper is also being used experimentally on Dahlias for this purpose.

Cut your flowers, don't let them die and dry

Showing where the shoots should be taken off as explained in the text. up on the bush: for that will stop your plants from blooming. The best time to pick the blooms is in the early morning while the dew is still upon them. 
There are a number of ways to keep Dahlias after they are cut. One is the hot water treatment, accomplished by placing a few inches of the stems of wilting blooms in water almost boiling hot for a few minutes--then taking them out and putting them quickly in cold water. Another method is to cut the stems of wilting Dahlias off under water-just above the bottom node. Let the stems remain in this water over night if possible, and the freshening effect will be almost unbelievable.

A week or so after frost has killed the vines, the tops should be cut off a few inches above the ground, and the clumps dug carefully in order not to break the roots. They may be safely stored just as soon as the wind and air has dried off the roots-an hour is all that is re. quired on a nice day. It is not necessary to place the clumps upside down in storage as some.

times advocated. Any cool cellar that does not freeze will do if not too dry. If your roots shrivel in storage, they need moisture-which can be supplied by sprinkling the cellar floor with water. If the roots begin to rot, the cellar should be ventilated to dry it off. Some varieties require more moisture in storage than others, and for that reason it will be difficult to keep all your varieties equally well in the same cellar.

Now, about fertilizer. In our opinion, there's nothing quite so good as a good application of stable manure that has been left on top of the soil all winter, to be turned under in the spring. But good manure is scarce, and most of us have to resort to the commercial fertilizers. Many growers recommend broadcasting bone meal over the soil as a top-dressing just prior to planting or soon after. This is probahly a good practice, but we prefer to make our first application of fertilizer about the time our Dahlias are eight or ten inches high, if the ground is poor. If the soil is good and the bushes look vigorous and thrifty, we do not make our first application until the buds begin to form. Our belief is that the early fertilizer (planting time) helps make the bush grow tall but has little or no effect upon the size of the blooms. We have seen ordinary sized hlooms on bushes so tall that it was necessary to pick the flowers from a step ladder--due to an immense amount of fertilizer at planting time and none thereafter. On the other hand, we have known very mediocre bushes in poor soil to produce fine flowers when fertilizer was applied just hefore blooming time.

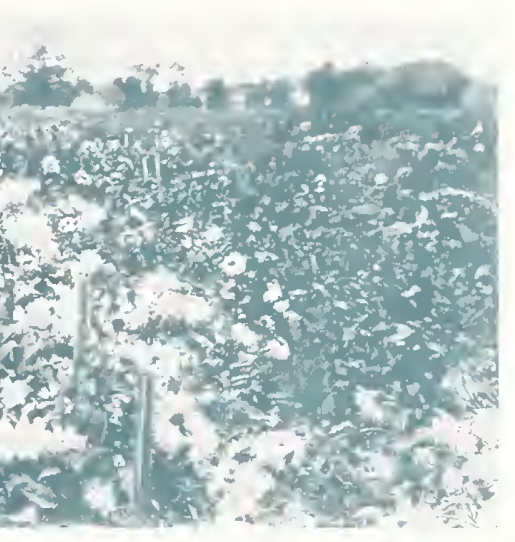

One of our fields in bloom. For size comparison, the stakes you see in the picture average less than one inch square. Below and at the top of page soil by cultivation.
So, regardless of how or when fertilizer was used earlier in the life of the plant, we make an application of fertil. izer just as the first buds are beginning to form. In two weeks, we make another application, on the opposite side of the plant. Two weeks later, still another - making three in all. An application, with us, is a good handful thrown upon the soil with enough force to scatter it within a foot of the base of the plant. The fertilizer is then mixed with the
The best time to apply fertilizer is just hefore or after rain. Plant food can not be assimilated without water.

Bone meal is a very good fertilizer-especially for foliage growth. There are a number of other good commercial fertilizers, probably the strongest of which is nitrate of soda. If you have never used nitrate of soda and intend to do so, we advise that you use great caution, for much damage may result from an over dose of this powerful stimulant. A little goes a long way.

We do not use any of these more concentrated fertilizers, preferring instead a well balanced potato or truck fertilizer. The analysis of the brand we use is $4-8-8$; meaning $4 \%$ nitrogen, $8 \%$ phosphoric acid and $8 \%$ potash. Any brand with the same or similar analysis should be equally as good.

If the plot where you intend to plant your Dahlias next season is in sod, the sod should be turned under in the fall, so that it can freeze and thaw several times during the winter. This kills whatever pests may he wintering there and gives the tangled mass of roots time to dis integrate and become workable.

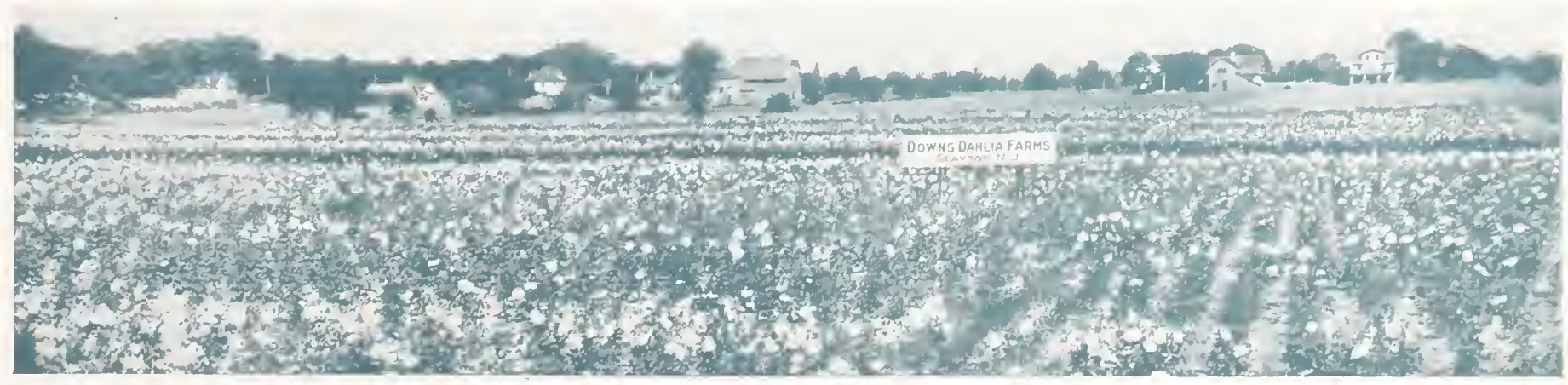


DOWNS DAHLIA FARMS-

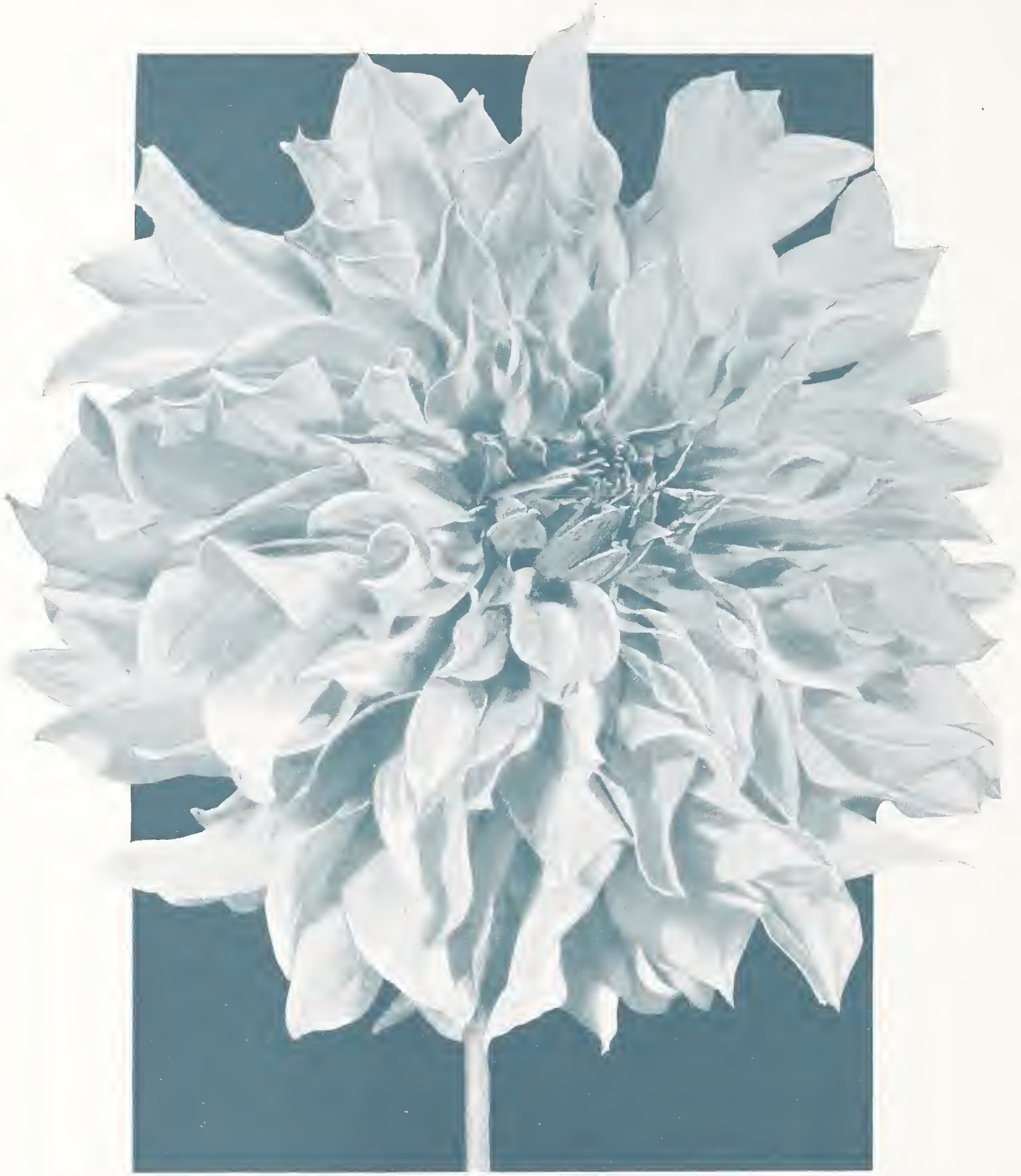

JANE COWL

(Our own origination)

Jane Cowl. Just imagine the ideal Dahlia bush fairly tall, with vigorous, dark green, leatherthick foliage Give it stems that are straight and strong, yet not clumsy. Then add monster blooms of glistening bronzy buff and salmon shades-blooms that will stop you every time you near them - and you have a mental picture of our own Jane Cowl. Jane Cowl is held on the stem just as it should be-looking at you and slightly up. Some blooms are even set squarely on top of the stem, Insulinde fashion. The flowers are immense, of the full petaled decorative type, with just enough twist to the broad petals to add the touch of refinement. Since its sensational debut as a seedling, this Achievement Medal winner has proved itself to be one of the really great Dahlias. No variety ever won more prizes in such a short space of time, nor made more friends wherever Dahlias are grown. At least two foreign countries are included in its triumphs. It was the predominant variety at the last New York Show.

Roots $\$ 7.50$ 
Adda Patterson. (Kemp.) A very good white hybrid cactus. The blooms are medium large and held well above the tall bush on straight, stiff stems. It keeps very well when cut. Tubers $\$ \mathbf{2 . 0 0}$

Alice Whittier. A beautiful cactus Dahlia of clear light yellow. Very large in size, with the many blooms held on excellent stems over a tall and vigorous bush.

Tubers $\$ 1.50$

Ambassador. Peaches and cream, mostly cream. This immense cactus Dahlia was sold for $\$ 50$ when first introduced, and has often been grown to sensational size.

Tuber $\$ .75$

A. O. Kenny. (Darling.) Large flowers of perfect form and great depth, carried on good stems. Color, a rich bronze buff shade of one tone, with the center tinted with bronze. Tubers $\$ 7.50$

Aztec Glory. (Broomall-Success.) One lady, passing through our field, found this variety. "Oh look," she called to her husband, "here's a whole dish of cole slaw." A very large decorative - one of those really BIG fellows -rich clear golden yellow in color, without tints or blends. The blooms are held erect on excellent stems. It makes a wonderful exhibition variety when cut, though the bush is not tall.

Tubers $\$ 5.00$

Barbara Redfern. (Redfern.) A free-blooming decorative of great size and depth. The color is a beautiful blend of old rose and old.gold. The large blooms are held on strong, stiff stems over a vigorous bush. This Dahlia keeps well when cut. Tubers $\$ 3.50$

Barbara Wear. (Seal.) Soft pinkish lavender, with petals shading to cream at outer ends. Deep good sized blooms on long straight stems.

Tubers $\$ 5.00$

Betty Ivins. (Sanhican.) A decorative of huge proportions. Color: Rich salmon, overlaid with an amber glow.

Tubers $\$ 5.00$

Bonnie Brae. An enormous decorative, so large its wiry stem cannot hold it erect. The broad flat petals are the color of cream, with pịk shadings.

Tubers $\$ .35$

Champagne. A statcly flowcr. Chamois in a light golden shade, growing darker toward the center. This is a decorative of good size, with excellent bush habits and fine stems.

Tubers $\$ .75$

City of Lawrence. An enormous yellow decorative-in depth as well as diameter. A free-blooming variety with good stems and a strong, husky plant.

Tubers $\$ .75$

Col. Chas. A. Lindbergh. (Sanhican.) Rose, overlaid and suf fused with old ivory, shading off to pale gold at the center. Hybrid cactus.

Tubers $\$ 5.00$

Cora Butterworth. (Chapman.) Large blooms of rich glis tening primrose yellow, held high above the foliage on stems that are perfect. It is a high centered decorative, with wavy petals, and can be easily grown from nine to eleven inches across, and almost half as deep. At the last New York Dahlia Show it won as the best undisseminated decorative. A Roll of Honor Dahlia. Plants only $\$ 5.00$

Datso. (Cottam.) This is a large well formed decorative of glowing deep rose-pink color. The stems are perfect and the foliage is lustrous and leathery.

Tubers $\$ 7.50$

Derrill W. Hart. (Broomall-Success.) A real autumn-colored decorative; copper shading to henna and brown. Tubers $\$ 7.50$

Eagle Rock Beauty. (Broomall.) Pink and cream in a glorious combination! Monster, well-formed decorative blooms that are full to the center, with petals reflexing toward the stem. A prolific bloomer of giant size, yet artistic, on first rate stems.

Tubers $\$ 3.50$

Earle Williams. Rich scarlet petals, tipped with white. Sometimes the blooms are all scarlet. Either way, this large decorative is a beautiful flower.

Tubers $\$ .75$
Eastern Star. (Dahliadel.) A dccorative of beautiful saffron, yellow, shading to old-gold-very effective in mass. The fullcentered blooms have great substance, and keep very well when used as cut-flowers. It has been awarded a Certificate of Merit by the Dahlia Society of New Jerscy.

Tubers $\$ 1.50$

Edna Ferber. (Sanhican.) One of our largest. A hybrid cactus of huze size, with petals curled and twisted to make a very full flower. Its color-a glistening coral shading to old-gold at the base of the petals-makes it one of the first to attract attention, both in the field and at the shows. It has won many prizes.

Tubers $\$ 3.00$

EI Dorado. Of golden yellow, with amber shadings, this decorative has attracted considerable attention at Dahlia shows. It keeps very well, has a fine stem that is unusually stiff and is one of the best for commercial uses.

Tubers $\$ 1.00$

Eliza Clarke Bull. (Boston.) An immense white decorative. It blooms freely on excellent stems that hold the flowers well above plants of medium height. This large deep Dahlia is one of those always in demand.

Tubers $\$ 2.00$

Eliza London Shepard. (Peacock.) A clear rich orange gold, reflex a deeper shade of the same color. The bush is a strong vigorous grower and holds the full centered flower from facing to upright on long stiff stems. Decorative.

Plants only $\$ 10.00$

Emma Marie. (Dahliadel.) Clear pink of lovely shade around a creamy white center. A deep, full centered, beautifully formed hybrid cactus bloom. The flowers are borne very freely on a robust bush with excellent stems. The roots are splendid keepers, and it is one of our best cut-flower varieties.

Tubers $\$ 1.00$
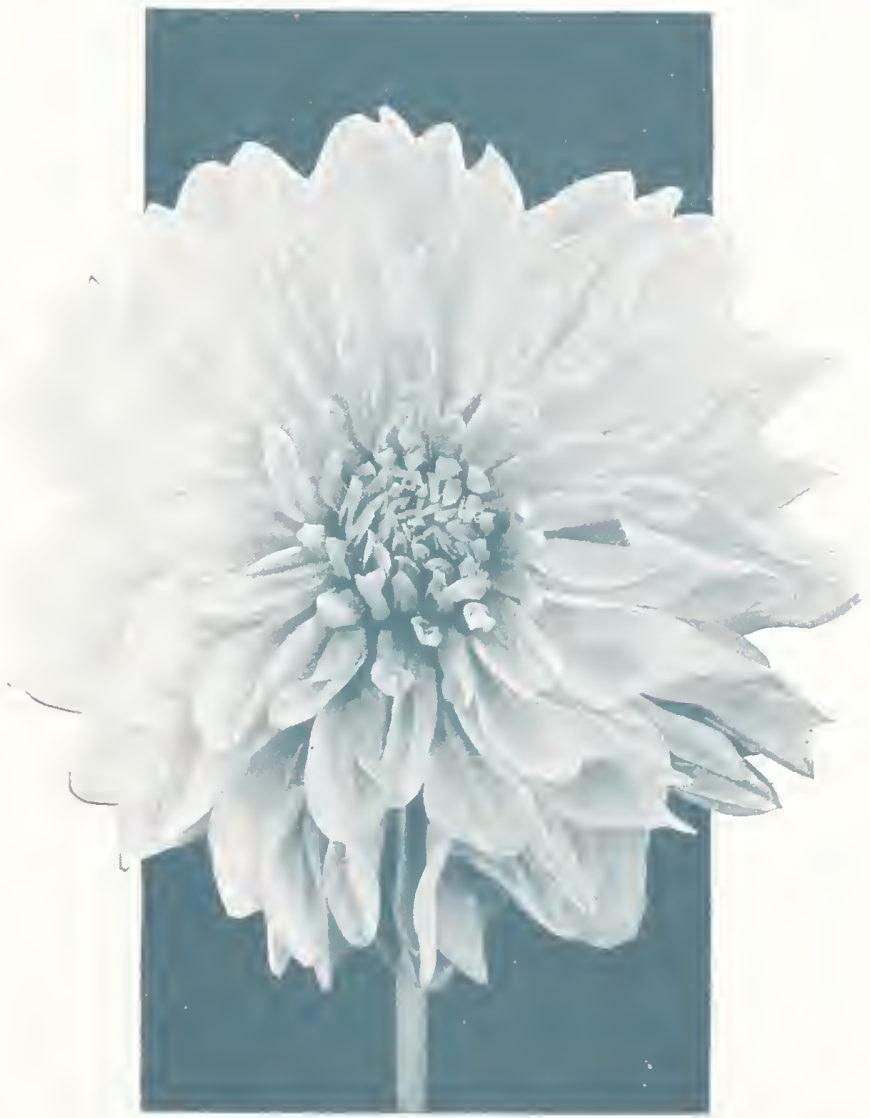

King Midas, one of the most impressive Dahlias of its color-rich clear yellow. See page 7 for description. 


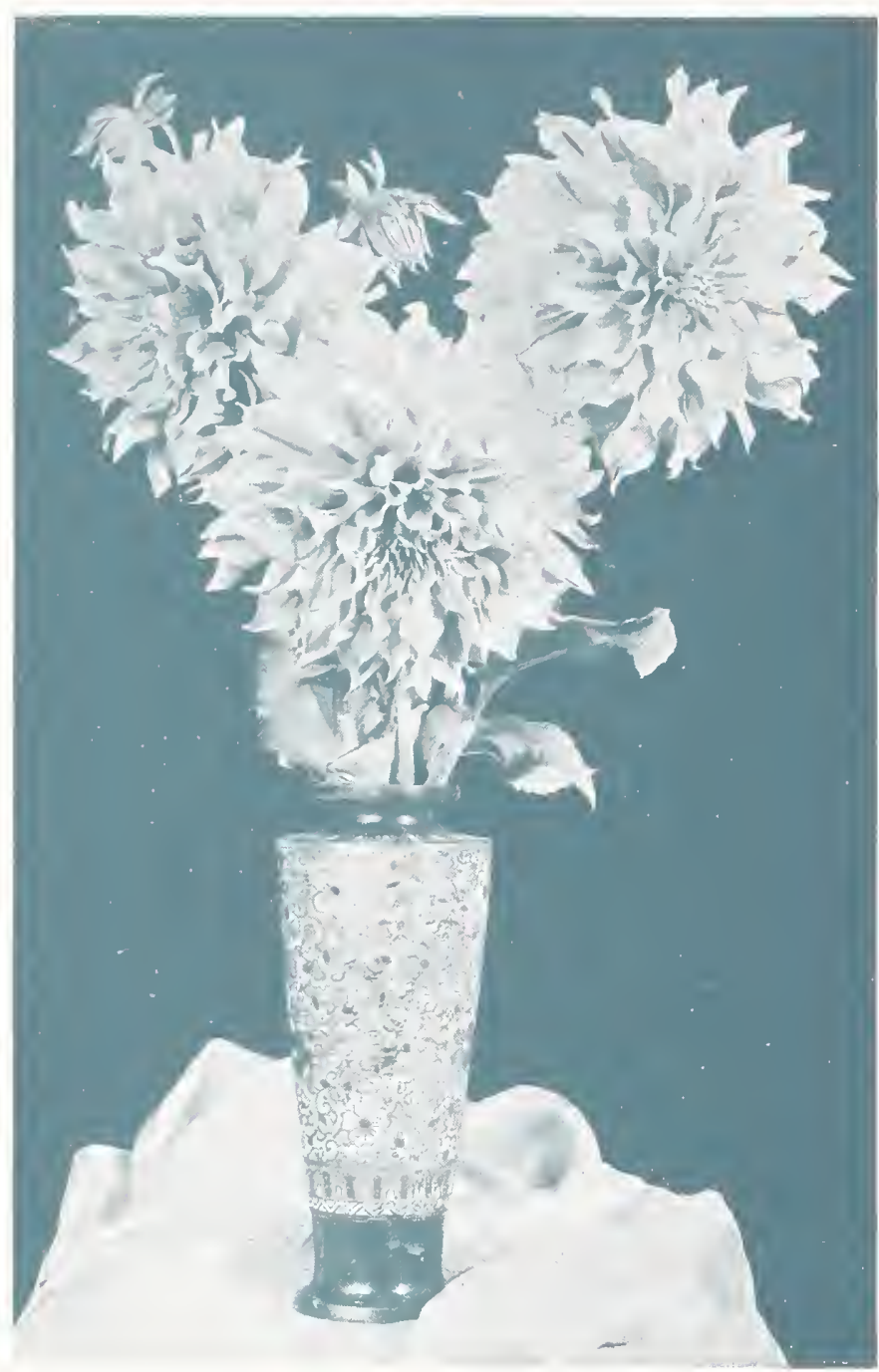

My Maryland, another of our own originations, is a pink of unusually delicate beauty. Described on page 8.

Fort Monmouth. (Kemp.) A gigantic, long, petaled hybrid cactus of spectacular rich claret, with a brightness unusual in red Dahlias - and it never burns. Of immense size and wonderful forma tion, this bloom is held on a stiff stem over a tall, strong.growing bush. It flowers freely and keeps well when cut. Tubers $\$ 7.50$

Fort Washington. This is a very large decorative of dark maroon. The bushes are tall and robust, with stems that are long and straight. It is an exceptionally good exhibition variety

Tubers $\$ 2.00$

F. W. Fellows. This beauty of orange-scarlet is larger than many a better known cactus. Its long, tightly twisted petals are incurved over a perfect center. We grow this for ourselves-just because we like it.

Tubers $\$ .7 j$

George Walters. Old gold, deep rose and salmon, blended. The biggest bloom we know of for the money.

Tubers $\$ .35$

Glory of Monmouth. (Kemp.) Wonderful garden and exhibition decorative, with petals that blend from a base of light orange to shades of strawberry-pink. The blooms are of moderate size and held over a medium bush on long, stiff stems. A good keeping variety with slowly opening petals of heavy texture.

Tubers $\$ 2.50$

Grandola. (Broomall.) This brilliant orange decorative of medium size was considered one of its originator's most beautiful introductions.
Harry Mayer. (Success.) One of the finest Dahlias for ex. hibition. The color is a beautiful silvery pink, with a deeper rose pink reverse. It has splendid habits and erect stems, with vigorous, dark green foliage.

Tubers $\$ 3.50$

Harry Sheldon, Jr. White, with an outside row of delicate shell pink petals. A dainty decorative, on a vigorous bush of spread. ing habit. It flowers profusely.

Tubers $\$ 1.00$

Hathor. (Seal.) One of the newest California varieties. A decorative of excellent form with vivid Oriental coloring-brilliant salmon, with orange, ivory, and gold shadings that defy descrip. tion

Tubers $\$ 2.00$

Ida Perkins. (Perkins-Montrose.) A pure white decorative, finely formed and with a substance of petal that makes it keep very well when cut. Upright and sturdy, this cleangrowing Dahlia is probably one of the best whites yet introduced. This variety has won the Achievement Medal at the Boston Dahlia Show.

Tubers $\$ 5.00$

Insulinde. Beautiful blooms of bronzy old-gold, held on top the stem umbrella fashion. A large decorative, unique in shape, with the outer petals dropping not unlike an Iris. A good bloomer, and worth several times its price.

Tubers $\$ .75$

Islam Patrol. Scarlet and gold-golden tips on scarlet petals. With its glorious coloring, great vigor and fine blooming qualities, this is one of our favorite hybrid-cactus Dahlias.

Tubers $\$ .75$

Jack O'Lantern. (Success.) Brilliant orange and rich red-the center petals tipped gold. With large blooms of this vivid color. ing held erect on a vigorous bush, this beautiful decorative attracts attention everywhere. It was awarded a Certificate of Merit by the Dahlia Society of New Jersey.

Tubers $\$ 2.50$

Jersey's Beacon. Chinese scarlet, with a paler reverse, which gives an unusual two-toned effect. A decorative almost globular in form, and of very good size.

Tubers $\$ 1.00$

Jersey's Beauty. Being an excellent keeper and beautiful pink in color, this is the most popular cut-flower variety in many markets. A decorative, with stem, bush and color to commend it.

Tubers $\$ .75$

Jersey's Daybreak. (Waite.) A beauty of pastel coloring-soft pink and ivory-white, but predominantly pink. This Dahlia is of splendid formation, with long stiff stems, holding the blooms over thick, leathery foli age.

Tubers $\$ 3.00$

Jersey's Gem. Another one of the famous "Jersey" group-a deco rative of delicate lavender pink that is extremely effective when arranged with white varieties. Has a fine stem, too.

Tubers $\$ .75$

Jersey's Glory. (Waite.) A large decorative of good form, with flowers of a yellow hue of orange. A robust grower, and blooms abundantly.

Tubers $\$ 7.50$

Jersey's Jewel. Long petals of clear pink. A decorative, large and with good habits; but not, with us, a prolific bloomer.

Tubers $\$ .75$

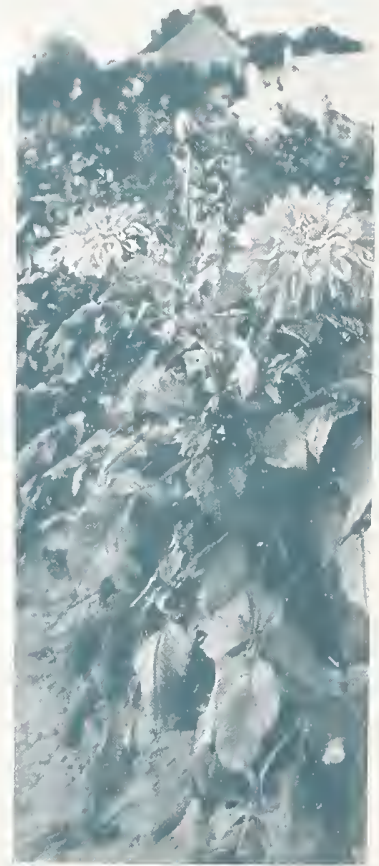

Sturdy bush growth 
Jersey's Masterpiece. (Waite.) Large blooms of brilliant apricot, with tints of orange; very deep, with long, graceful petals and a formation similar to Insulinde. The many flowers are carried on strong, cane-like stems, and the foliage is of good texture.

Tubers $\$ 5.00$

Judge Marean. A large beauty of salmon pink and golden yellow, beautifully blended. A prolitic blooming variety, of the decorative type, on stiff, wiry stems.

Tubers $\$ .75$

Kalif. A bright scarlet Dahlia of the hybrid cactus type. The good. sized blooms are borne very freely. They keep well, have fine stems, and are excellent for commercial uses.

Tubers $\$ .50$

Kathleen Norris. (Sanhican.) A bloom of gigantic proportions - true rose pink, later deepening to mallow pink. It was awarded first prize as the best flower in four great Eastern Shows in addition to innumerable other awards as an undisseminated seedling.

Plants only $\$ 5.00$

Kemp's Violet Wonder. (Kemp.) Impressive blooms of rich violet, with an underlying tone of royal purple. A true decorative of massive proportions, borne on strong stems well above the tall plant. This remarkable Dahlia has been Certified, and has been a winner at many a Dahlia show.

Tubers $\$ 7.50$

King Midas. (Peacock.) A plant not tall, but strong and sturdy, bearing immense exhibition blooms of beautiful golden yellow. The flowers are full centered and borne on the best of stems. King Midas is one of the finest Dahlias we ever grew.

Roots $\$ 10.00$

La Roda. (Broomall.) A large, well formed flower of silvery rose pink on strong stems.

Tubers $\$ 7.50$

Lavender Gem. (Sanhican.) A beautiful thick decorative, lavender in color, with the broad petals terminating in curled points. One of the first to bloom-and still flowering when frost comes.

Plants only $\$ 2.50$

Lolita Velasco. (Boston.) Pure white in color, almost perfect in form, and with firm textured petals that make it keep a long time. This artistic, narrow-petaled cactus is one of the best of its type.

Tubers $\$ .75$

We are reprinting below a letter from last year's catalog-because it tells so well how long big Dahlias may be kept.

Mr. O. Downs,

Downs Dahlia Farms.

Silver Creek, N. Y.

DEAR SIR:

I want to tell you something about your Dahlias. I travelled five hundred miles to see the New York Show.

A couple of hours before the close of the show I persuaded your man to let me have a few blooms to take home to show my wife but he did not think it could be done on account of the distance. With the help of a friend we took four blooms, two of "My Maryland" and two "Jane Cowls" used one of the association tins and filled it about two-thirds full of peat around the stems and started for Buffalo, when I boarded the train the porter was starting to make up the berths, and I offered him a dollar if he would find some place to put the flowers until we got to Buffalo. He said, "Good Lord, ah can't find no place to put them sun flowers, they"s too big!" "Well," I said, "alright then, throw them under my bed," and went into the smoking room disgusted with the porter, and sure enough when I came to go to bed he had thrown them under my bed. You can imagine my surprise when I got up in the morning near Buffalo and found the flowers just as nice as when I took them out of the show room. I reached home about nine o'clock in the morning and took the blooms and freshened them up in cold water and had them in the window of the First National Bank for two days. Everybody that saw them raved about them.

So I can truthfully say Downs Dahlias are hard to beat. These flowers were cut one day before the show, kept two days at Madison Square Garden and two days in the Bank window here.

$$
\text { Yours truly, HENRY SCHEyer. }
$$

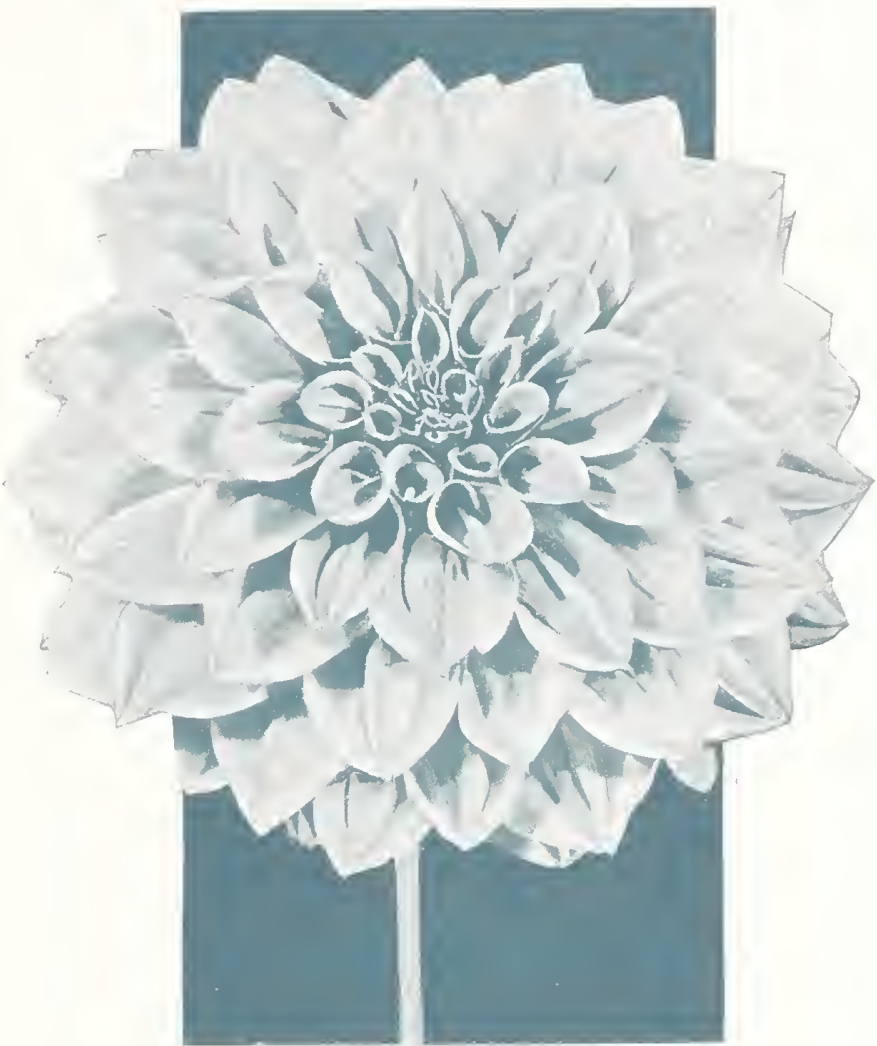

Harry Mayer is described on page 6.

Margaret Woodrow Wilson. (Sanhican.) An exhibition decora tive, large and of great beauty. The pink on the reverse of the petals, reflecting on the white face gives an exquisitely opalescent effect.

Tubers $\$ 1.50$

Marion Broomall. (Broomall.) Pink and white and beautiful! A hybrid cactus of large size that should be in every garden.

Tubers $\$ 1.50$

Mariposa. The incurved petals of this perfectly formed hybrid cactus are of delicate pink, often flushed violet and giving the effect of lavender. Large flowers on straight, strong stems.

Tubers $\$ .75$

Marmion. (Mastick.) Immense blooms of golden yellow with a bronze suffusion, and a deeper bronze in the full, high center. One of the largest decorative varieties and of excellent formation. Its long straight stems and good plant may be classed with the best. This was one of the highest scoring Dahlias at the Trial-Grounds, and has won many prizes.

Tubers $\$ 2.00$

Martha Kemp. (Kemp.) Warm buff in color, shading to apricot-yellow. These very deep blooms are of good size and borne on fine stems on a plant of great vigor. Their good keeping qualities make them very desirable for house decoration because their petals never drop. Tubers $\$ 7.50$

Miraflora. (Broomall.) Violet pink, with tints of white. The petals are long, narrow, and almost straight. It blooms very freely on good strong stems, and is one of the largest cactus Dahlias we know.

Tubers $\$ 1.00$

Mrs. Alfred B. Seal. (Seal.) A California Dahlia of unusual color -absolutely pure rich glowing old rose. Large deep decorative blooms held proudly erect over a fine bush.
Tubers $\$ 15.00$ 


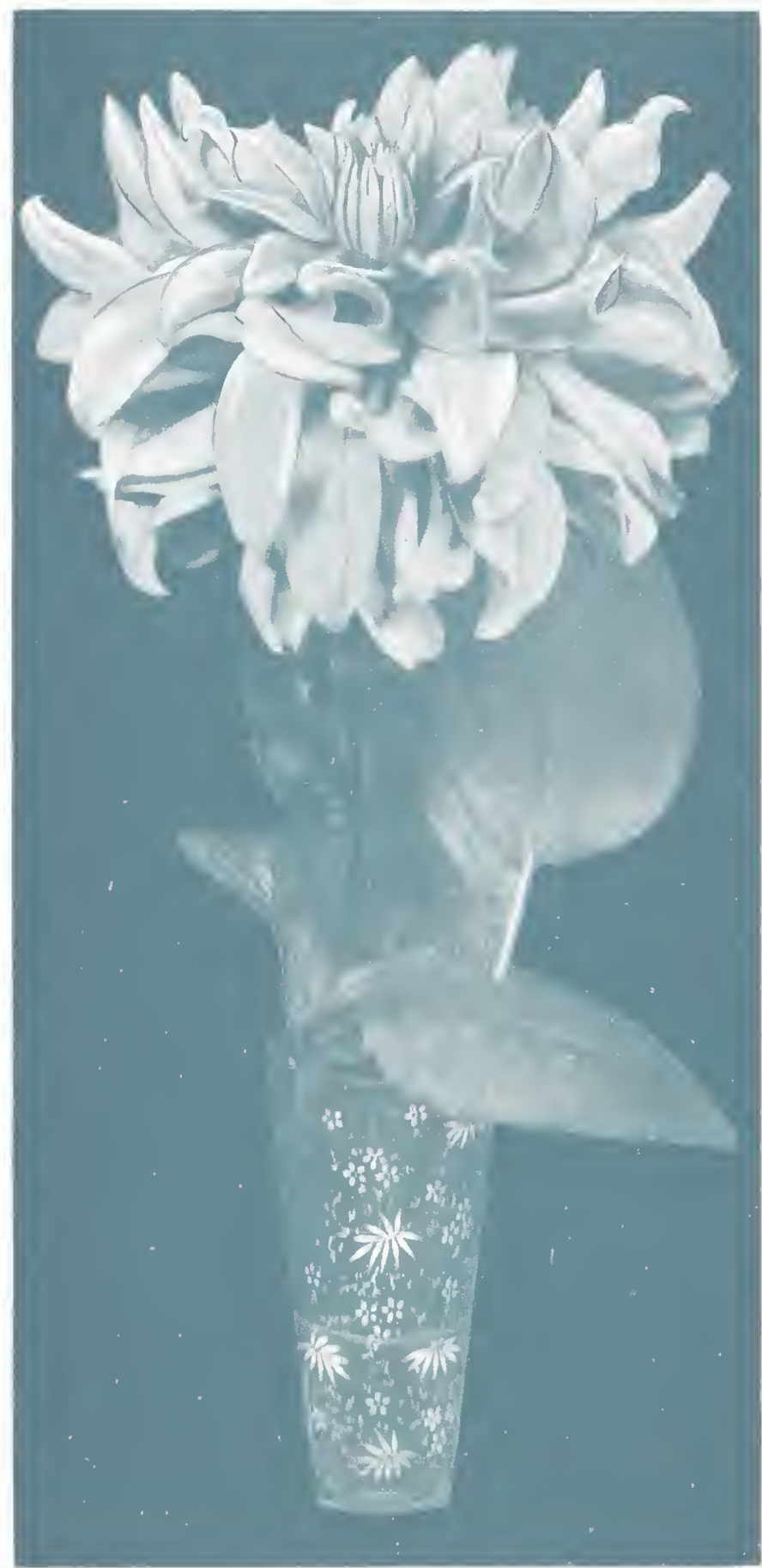

THE DEPTH OF JANE COWL

The late Mr. A. O. Kenny, former secretary and treasurer of the Ontario Dahlia Society and a great admirer of the Dahlia Jane Cowl, sent us this picture. Mr. Kenny wrote that the bloom shown won for him at the Canadian National Exhibition-it was twelve and one-half inches across and six inches deep. Many of our customers have written in praise of Jane Cowl's size, reporting blooms as much as fourteen inches across them; which is enormous when the depth of this Dahlia is considered.
What one man says:

DOWNS Dahlia Farms,

Dec. 24, 1929.

Clayton, New Jersey.

Dear Mr. Downs:

In our search for dahlias with sufficient vigor to produce good flowers in the famous "corn weather" of the Sioux country, we have had some experience with Jane Cowl that we think may interest you.

Early last June we put out two green plants. After they got a good start we pinched out the tops. One plant threw twelve branches and the other eleven. As they grew we disbudded carefully, leaving only the terminal bud on each of the twenty-three branches. Twenty of these matured and the other three would have made it if the frost had held off a week longer.

The flowers opened at such intervals and lasted so long that we had a good display all during the blooming season. The blos oms were nine to twelve inches in diameter, every one was perfect and was held in just the right position for exhibition on stems averaging more than three feet in length.

On September 6 the first flower, although not ready to cut, won first prize as the best decorative, and sweepstakes as the best bloom in our local dahlia show. From that time until killed by frost October 21, Jane Cowl was undoubtedly the most talked of and most visited dahlia ever grown in Sioux City. Folks who have seen dahlias on both coasts, and who know good ones when they see them, said they had never seen better and would not have believed such flowers possible here.

This was also our first experience with green plants and we were prepared, by the criticisms of this method of propagation, to be satisfied with a small crop of roots. To our surprise, one clump has thirty and the other thirty-five roots. We have not divided them yet but they are keeping well and we ought to have a larger increase than we usually get from tubers of other good varieties.

Truly, Jane Cowl seems to have everything. If she continues as she began she will easily hold her position at the top of the "Corn Climate" Honor Roll as the best ever for this climate.

If you have any other new ones even approximately as good we would like to try them.

Sincerely yours,

\section{A. R. Gephart}

Mrs. Carl Salbach. Soft rose pirk blooms, flushing lavender - and many of them. This decorative keeps very well when cut, and has long, stiff, straight stems that do not require disbudding.

Tubers $\$ .50$

Mrs. I. deVer Warner. This clear lilac-rose decorative is remark able for its purity of color. The plant is vigorous and prolific, bearing many large, long-keeping blooms on fine stems. Taken all around, this is one of the best Dahlias of low price.

Tubers $\$ .50$

Mr. Alexander Waldie. In color similar to Bonnie Brae. It has a better stem than that variety, though it is not quite so large. A decorative.

Tubers $\$ .50$

My Maryland. (Our own origination.) A beautiful Dahlia of clear rich pink, with hardly a suggestion of lavender. The women love it! Each petal is gracefully twisted and twirled, and daintily tipped with a touch of ivory that adds greatly to its charm. Fairly tall, with foliage of insect resisting thickness, My Maryland is one of the healthiest varieties we grow. The stems are straight and strong, yet graceful, and hold the large bloom in an ideal position. As a seedling, this Dahlia won first prize at the Atlantic City Show of the New Jersey Dahlia Society, and, at the same Show, won the Achievement Medal. It also won as the best undisseminated hybrid-cactus seedling at the New York Show. It was awarded a Certificate of Merit and was listed on the Roll of Honor.

Roots $\$ 7.50$ 
Nancy Sue Lang. (Broomall.) Striking hybrid decorative with the color a combination of red, copper, and gold. A giant in size and of star-like formation, on a plant not tall but very rohust. The stems are all that can be desired.

Tubers $\$ 2.50$

Papillon. (Boston.) This beautiful hybrid cactus is old rose, with a golden suffusion. The blooms are large, on a medium tall bush which is very prolific.

Tubers $\$ .75$

Paul Michael. A big decorative, almost the color of gold. Blooms of this variety often reach ten inches across. A fine garden Dahlia, but not the best of keepers after being cut. Tubers $\$ .50$

Pop Stewart. (Sanhican.) Marvelous in coloring-an exquisite shade of lilac-pink. It is a decorative of medium. large size, but can be grown large by fertilizing and disbudding. Having full centers ordinarily, unusual color ing, great stems, and free-blooming qualities, it makes one of the best varieties for cut-flowers. It has been Certificated by the Dahlia Society of New Jersey and has won many prizes.

Tubers $\$ 1.25$

President Hoover. (Peacock.) With the full high center of Papil lon, the stems of Jersey's Beauty, and a color all its own--peach red, blending to begonia rose. An early and persistent bloomer, strong and vigorous.

Plants only $\$ 7.50$

Primula Rex. (Broomall.) Immense in size, and one of the best. A decorative of very bright cream color. The medium to tall plant is a very profuse bloomer. With every other good quality to commend it, this is also one of the largest Dahlias, and should be in every garden.

Tubers $\$ 1.50$

Queen of the Garden Beautiful. (Burns.) A gigantic decorative of very distinctive form. Primrose-yellow in color, with full centers and excellent stems. This is a Dahlia of real merit, and has won a great many prizes. Great Dahlia for exhibition at shows.

Tubers $\$ 2.00$

Robt. E. Lee. (Peacock.) A brilliant glowing red hybrid cactus, carried facing to upright on cane stiff stems. A 1929 Roll of Honor Dahlia, and a good one.

Plants only $\$ 10.00$

Robert Treat. This is a favorite with certain florists we know. Almost the color of the American Beauty rose. It bears abundantly large blooms that are held erect over a tall and vigorous plant. Decorative type.

Tubers $\$ 1.00$

Rollo Boy. Delicate amber, shading to old gold. The hybrid-cactus blooms are large, they keep well, and are held on the best of stems.

Tubers $\$ 1.00$

Roman Eagle. (Sanhican.) Medium to large flowers of brilliant burnished copper color-a very attractive autumn shade. A profuse bloomer, with stiff stems and dark green foliage. Deco rative.

Tubers $\$ 1.00$

Rosa Nell. 'This is not a prolific variety, but every bloom "rings the bell." Immense flowers of hright cerise, without tints or shad. ings of any kind. A deep, full decorative, with fine stems. One of our favorites.

Tubers $\$ .75$

Sagamore. (Badetty.) One of the finest golden yellows, for commercial purposes especially. It is held on strong stems over a sturdy plant and is very prolific. With its great substance and keeping qualities, it makes a first-class cut-flower. Tubers $\$ .75$

Salbach's White. (Salbach.) This full, deep, white decorative, with its firm texture and fine stem and habit, will make a worthwhile addition to any Dahlia garden.

Tubers $\$ 1.75$

Sanhican's Bluebird. (Sanhican.) An uncommon blending of violet with a bluish tint that comes nearer to blue than any other Dahlia. A large decorative with strong, wiry stem. In combination with Sanhican's Gem, it makes a glorious blending of colors.

Tubers $\$ 1.50$
Sanhican's Gem. (Sanhican.) A decorative of clear old rose, with a glistening sheen in the sunlight. This variety has been awarded a Certificate by the Dahlia Society of New Jersey, and is one of Sanhican's best.

Tubers $\$ 1.50$

Sanhican's Nymph. (Sanhican.) A 1928 introduction of great beauty and good size. It is decorative in type, rich primroseyellow, with the reverse of its quilled petals touched with rose It has a fine center, and is well held on a plant of medium tall habit.

Tubers $\$ 5.00$

Sanhican's Queen. (Sanhican.) Indescribable shades of carmine rose, deepening toward the tight center. Excellent habit, with the rigid stem carrying the flower well above the foliage. This is one of our favorites

Tubers $\$ 5.00$

Seal of Connecticut. (Alling.) Fine clear, bright, golden yellow Its immense decorative blooms are borne very freely on a bush of moderate herght. A very large Dahlia and a good one.

Tubers $\$ 2.50$

Seal's Californian. (Seal.) Biooms so perfect as to seem almost of wax. The bright golden yellow centers shade to lighter yellow outer petals whose tips are rosy bronze. Decorative. Roots $\$ 7.50$

Shirley E. Shattuck. Here is a Dahlia of different formation from any we have ever seen. A decorative of orchid lavender. Fine stems hold the many flowers over a bush of scmi-dwarf habit.

Tubers $\$ 1.00$

Shudow's Lavender. Silvery lavender, shaded with white, this beautiful decorative is without a superior in lavenders. The large blooms are held erect on excellent stems over a tall plant with lace-like foliage. Requires more care than most Dahlias to bring it to its best-but well worth the trouble.

Tubers $\$ 1.00$

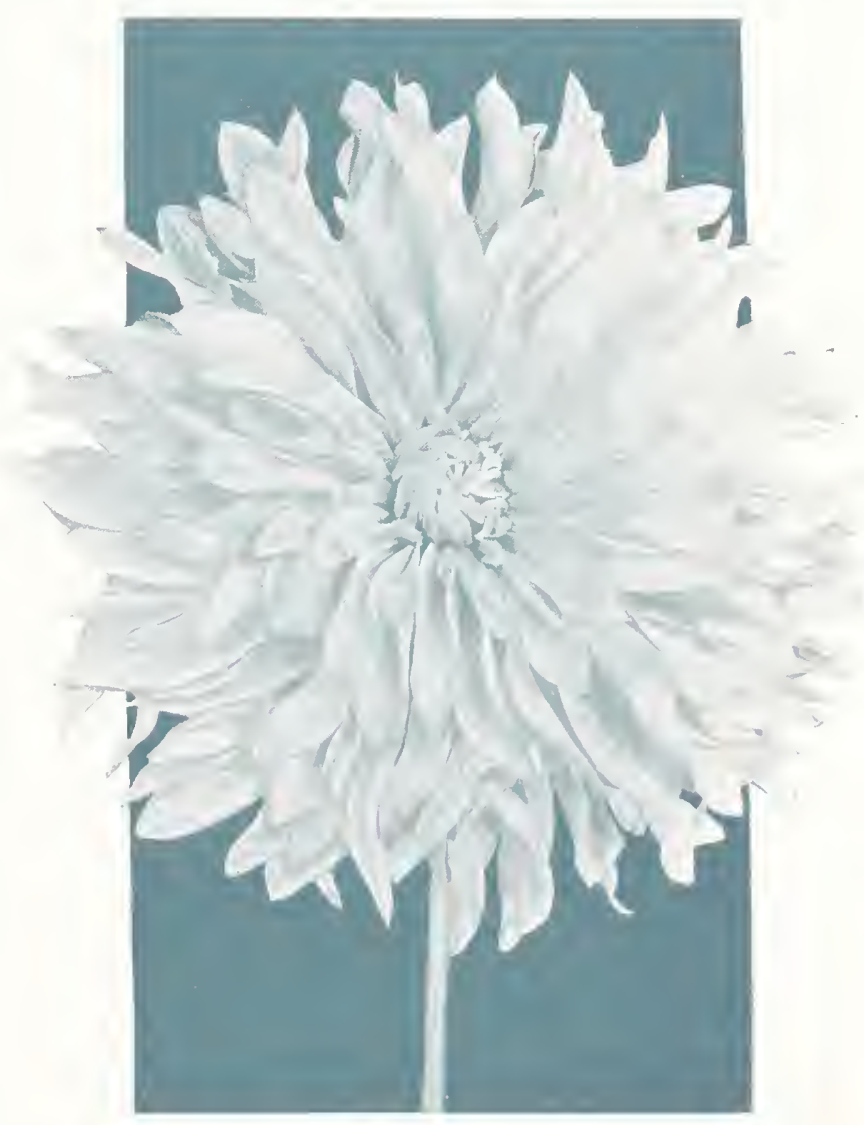

We recommend Waldheim Sunshine. See page 11 
DOWNS DAHLIA FARMS_....... A [

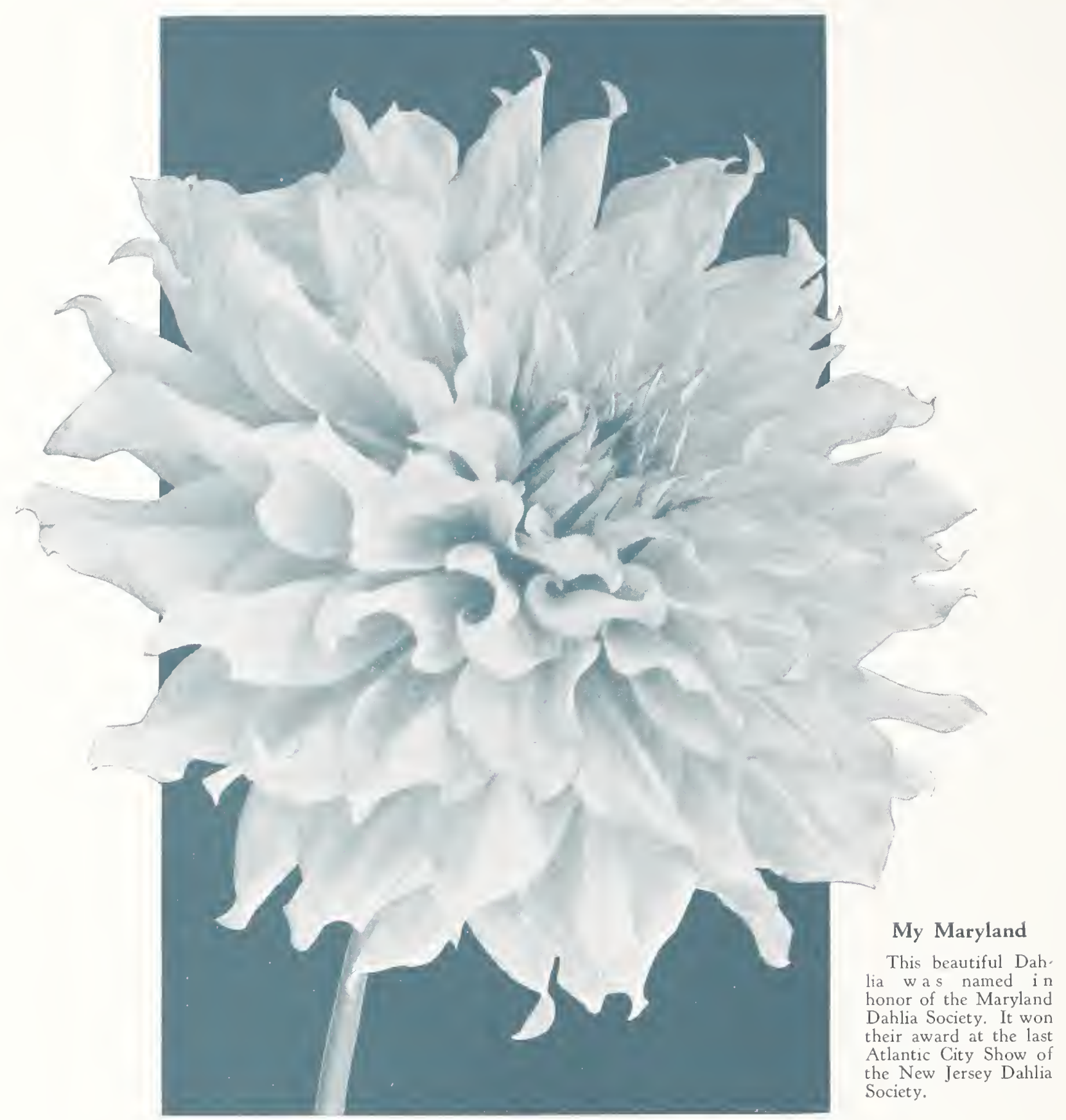

Silverado. (Seal.) A distinctive, large-petaled hybrid cactus from California. Huge blooms of white, with lavender shadings at the center. The plant is tall and vigorous, and the stems are good.

Tubers $\$ 3.00$

Siskiyou. A ludicrous little bush, stoutly holding up sevcral enormous blooms of pinkish maluve-ten or more inches across them. It's just right to use as a border for your Dahlia garden.

Tubers $\$ 1.50$

Susan G. Tevis. An extremely soft and pleasing shade of lilac, with a bluer undertone. Another decorative, and a good one.

Tubers $\$ .50$
The Bandit. Narrow petals-- that curl and twist-of mahogany-red and pure gold; a dazzling combination. The large hybrid-cactus blooms are held erect on black wire-like stems. It was awarded a certificate by the A. D. S.

Tubers $\$ 1.00$

The Lemonade. (Ward.) This large clear yellow decorative has been called one of the finest Dahlias ever originated in New England. It is commendable in every way.

Tubers $\$ 2.50$

The U.S. A. With a vivid orange coloring that has made it very popular. A large flower of the peony type, with fine stem.

Tubers $\$ .75$ 


\section{Green Plants}

The husky little "baby bushes," as shown on page twelve, often start to make tubers even before we send them out. On page twelve is shown the careful packing method that assures their safe arrival at almost any destination in this country. Although these green plants require a little more care in planting than roots, and will not mature quite so quickly, we know they will give a full measure of satisfaction-especially when it is remembered that you receive two plants at the price of one root.

\begin{tabular}{|c|c|}
\hline O. Kenny & $\$ 3.75$ \\
\hline ztec Glory $\ldots \ldots \ldots \ldots \ldots \ldots$ & 2.50 \\
\hline rbara Redfern & 1.75 \\
\hline 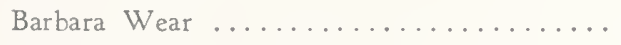 & 2.50 \\
\hline tty Ivins & 2.50 \\
\hline ora Butterworth & 5.00 \\
\hline ol. Lindbergh $\ldots \ldots \ldots \ldots \ldots \ldots \ldots$ & 2.50 \\
\hline$\ldots \ldots \ldots \ldots \ldots \ldots \ldots \ldots \ldots \ldots \ldots$ & 3.75 \\
\hline 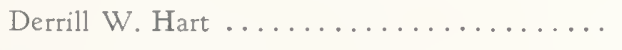 & 3.75 \\
\hline agle Roc's Beauty ..... & 1.75 \\
\hline dna Ferber & 1.50 \\
\hline Shepard..$\ldots \ldots \ldots \ldots \ldots$ & 10.00 \\
\hline$h \ldots \ldots \ldots \ldots \ldots \ldots \ldots \ldots$ & 3.75 \\
\hline f Monmouth .............. & 1.25 \\
\hline 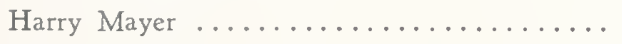 & 1.75 \\
\hline Hoover .................. & 7.50 \\
\hline Ida Perkins ........... & 2.50 \\
\hline Jane Cowl ...... & 3.75 \\
\hline Jersey's Glory .. & 3.75 \\
\hline 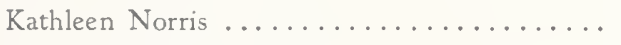 & 5.00 \\
\hline Kemp's Violet Wonder ............... & 3.75 \\
\hline$\ldots \ldots \ldots \ldots$ & 5.00 \\
\hline r Gem $\ldots \ldots \ldots \ldots \ldots \ldots \ldots \ldots$ & 2.50 \\
\hline $\mathrm{n} \quad \ldots \ldots \ldots \ldots \ldots \ldots \ldots \ldots \ldots \ldots$ & 1.00 \\
\hline 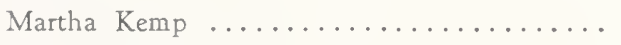 & 3.75 \\
\hline Mrs. Alfred B. Seal.................. & 7.50 \\
\hline My̆ Maryland $\ldots \ldots \ldots \ldots \ldots \ldots \ldots$ & 3.75 \\
\hline Hoover .. & 7.50 \\
\hline E. Lee $\ldots \ldots \ldots \ldots \ldots \ldots \ldots \ldots$ & 10.00 \\
\hline s White..$\ldots \ldots \ldots \ldots \ldots \ldots \ldots$ & 1.00 \\
\hline Sanhican's Nymph & 2.50 \\
\hline Sanhican's Queen $\ldots \ldots \ldots \ldots \ldots \ldots$ & 2.50 \\
\hline 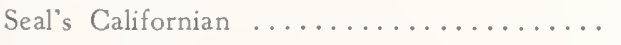 & 3.75 \\
\hline The World ................ & 3.75 \\
\hline Thos. A. Edison ... & 10.00 \\
\hline Treasure Island .......... & 3.75 \\
\hline Sunshine $\ldots \ldots \ldots \ldots \ldots \ldots$ & 3.75 \\
\hline Beauty..$\ldots \ldots \ldots \ldots$ & 5.00 \\
\hline
\end{tabular}

We make no extra charge for packing these plants, and pay carriage charges on all orders amounting to ten dollars or more. Just plant them as soon as they arrive, water well, and shade them during the hottest part of the first few days and you will have Dahlias already up-without waiting the two weeks or so required by roots.
The World. (Dahliadel.) The coloring is unusual-rich deep rosy magenta overlaid garnet, with silver shadings on the edges of its petals. A rich and beautiful combination of colors. Perfect, full centers, 8 to 10 inches across and half as deep. Tubers $\$ 7.50$

Thomas A. Edison. (Dahliadel.) An exhibition decorative of royal purple, with staghorned petals. A thrifty grower, with dark green insect resistant foliage and cane stiff stems. A Roll of Honor Dahlia.

Plants only $\$ 10.00$

Treasure Island. (Dahliadel.) Color, bright apricot with gold and rose suffusion and shadings. Flowers are held erect with full centers throughout the season. A Dahlia that will score high, both early and late in the season.

Tubers $\$ 7.50$

Trentonian. A coppery-bronze decorative, held straight across the top of a cane-like stem. Petals are broad and flat, forming an attractive flower of good size that has won many a prize. Certificated by the D. S. of N. J.

Tubers $\$ .75$

Valiant. A beautiful bright red cactus, similar in shape to F. W. Fellows, with long slender petals curving forward over the center.

Tubers $\$ .75$

Waldheim Sunshine. (Peacock.) Another of our largest varieties. A huge deep yellow decorative, with twisted, wavy petals that relieve the immense size from stiffness. See the picture on page 9. The bush and stem are excellent.

Tubers $\$ 7.50$

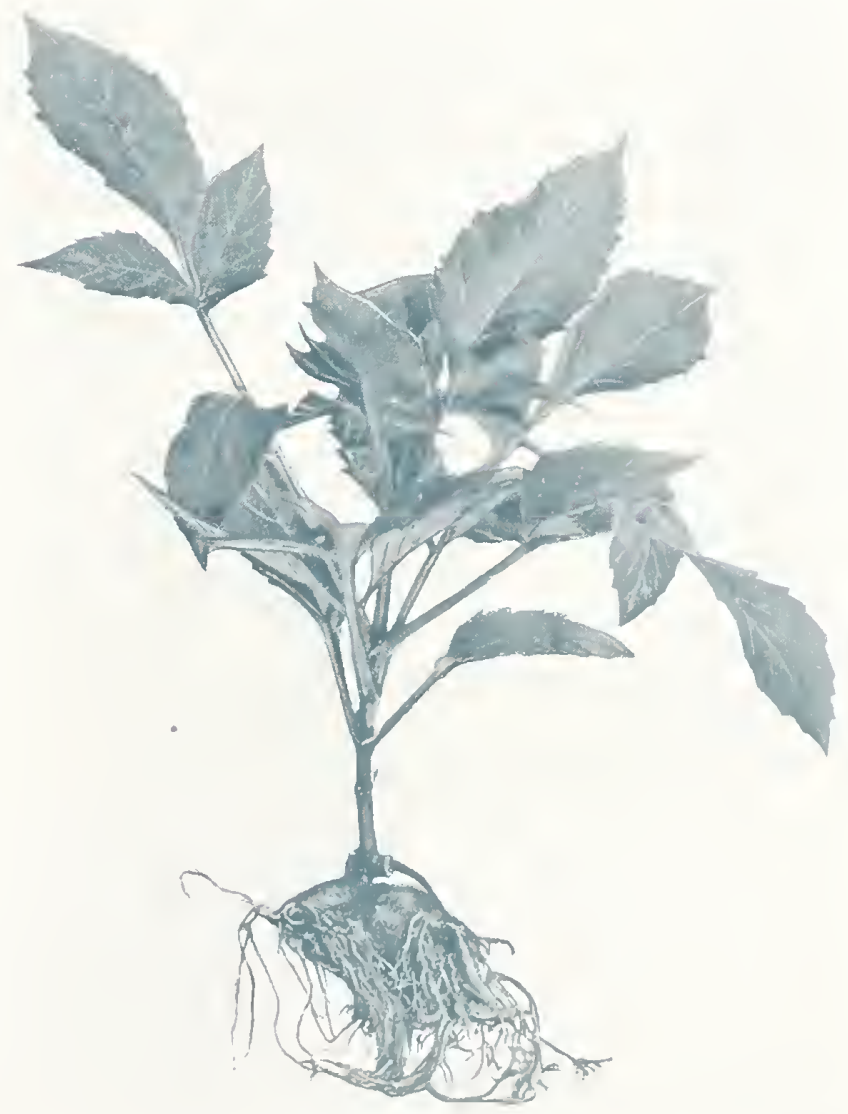

Note the root system and tubers already started to form on this husky young green plant. Such plants, in little pots, cost only half as much as roots. List of varieties we can supply and their prices are shown on this page. 


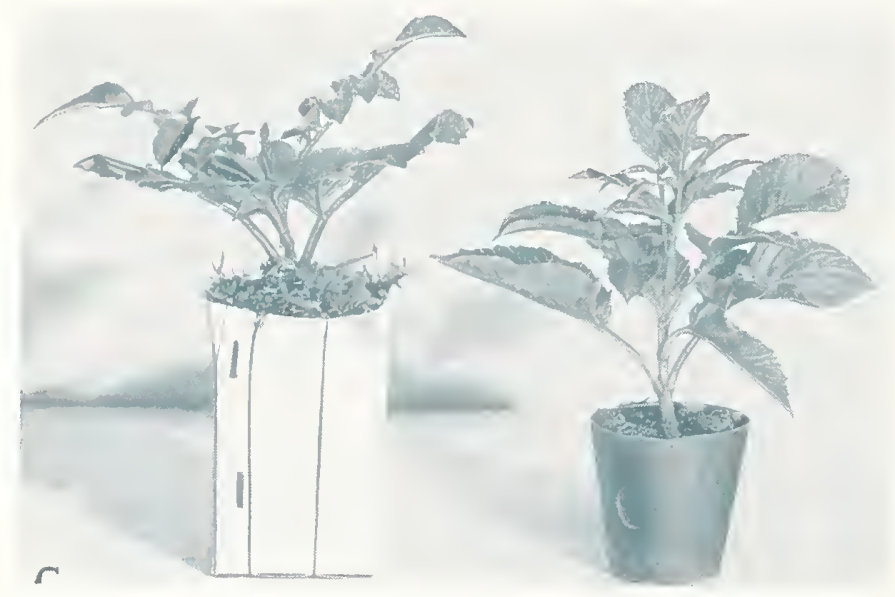

In preparing for shipment, the plant is taken from the clay pot and placed in the paper one shown on the right; then packed in a square nest of moss as shown on the left.

Watchung Sunrise. (Smith.) Large deep blooms, with a narrow clear rose-pink margin around each golden amber petal. A decorative of unusual formation-the outer petals curving backward almost to the stem. Created a sensation at the New York Dahlia Show.

Tubers $\$ 5.00$

World's Best White. (Murphy.) Its name is not far wrong, for this is one of the finest white Dahlias yet produced. A large decorative with a full center. A fine exhibition flower, and its excellent stem, good keeping qualities, and abundance of blooms give it a rating second to none for cutting.

Tubers $\$ 1.00$
White Sister. A pure white decorative of lovely formation.

Tubers $\$ 1.00$

Wizard of Oz. Very large flowers of amber pink, shaded with salmon. Decorative, with the blooms borne profusely on fine stems. An all round, good Dahlia that will grace any garden.

Tubers $\$ 1.00$

Yellow Beauty. (Wood.) Decorative, pure empire yellow in color. Splendid habit and style of growth. A seedling of Jersey's Beauty and possessing all the good points of its parent.

Tubers $\$ 10.00$

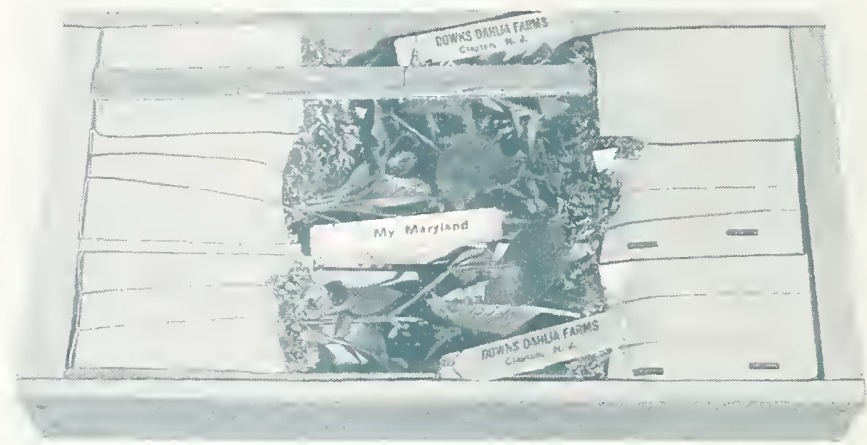

The moss packed cartons holding the plants are then packed tightly in ventilated corrugated or wooden boxes. Long sticks (on which the tags are fastened) hold each plant in its proper position at the end of the box. We have sent green Dahlia plants safely all the way to the state of Washington in this manner.
Our policy is to grow, in the best way we know, only a few of the finest Dahlia varieties; to produce them in sufficient quantity to enable us to fill every order with the choice roots of a large supply; and to do our best to give each cus. tomer the satisfaction he has a right to expect.
Our guarantee is that our stock will reach you in first class condition, be true to name, and meet with your approval in every respect. You are requested to return at once any shipment proving otherwise-in which case we will refill the order or refund your money, whichever you prefer.

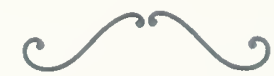

\section{Downs Dahlia Farms \\ Clayton, New Jersey}



